\title{
The cytotoxic activity of pine needles ethanolic extract of Pinus merkusii on HeLa cell lines
}

\author{
Annise Proboningrat ${ }^{1 *}$, Amaq Fadholly ${ }^{1}$, Sri Agus Sudjarwo ${ }^{2}$, Fedik Abdul Rantam ${ }^{3,4}$, and \\ Agung Budianto Achmad ${ }^{5}$ \\ ${ }^{1}$ Doctoral Program in Veterinary Science, Faculty of Veterinary Medicine, Universitas Airlangga, \\ 60115 Surabaya, Indonesia \\ ${ }^{2}$ Department of Pharmacology, Faculty of Veterinary Medicine, Universitas Airlangga, 60115 \\ Surabaya, Indonesia \\ ${ }^{3}$ Department of Microbiology, Faculty of Veterinary Medicine, Universitas Airlangga, 60115 \\ Surabaya, Indonesia \\ ${ }^{4}$ Research Center for Vaccine Technology and Development, Institute of Tropical Disease, Universitas \\ Airlangga, 60115 Surabaya, Indonesia \\ ${ }^{5}$ Department of Health, Faculty of Vocational Studies, Universitas Airlangga, 60115 Surabaya, \\ Indonesia.
}

\begin{abstract}
Several efforts have been made to discover new anticancer agents based on natural ingredients. Meanwhile, previous studies have shown that different Pine genus species exhibit cytotoxic activity against various types of cancer cells. This plant is rich in phenolic compounds, especially procyanidins, flavonoids, and phenolic acids. Therefore, this study aims to investigate the in vitro cytotoxicity of Pinus merkusii needles extract on HeLa cancer cell lines. The cytotoxicity assessment was measured using MTT assay and expressed as $\mathrm{IC}_{50}$ value. The results showed that the ethanolic extract poses a dose and time-dependent cytotoxic activity with an $\mathrm{IC}_{50}$ value of $542.5 \mu \mathrm{g} / \mathrm{ml}$ at 48 hours of incubation. Based on this result, Pinus merkusii needles' ethanolic extract has the potential of a novel candidate for an anticancer agent.
\end{abstract}

\section{Introduction}

Cancer is a complex disease characterized by aberrant cell growth and invasion of neighboring cells as well as tissues, which contributes to the causes of mortality and morbidity globally [1-2]. The International Agency for Research on Cancer (IARC) estimated that 18.1 million cases and 9.6 million deaths occurred in 2018 and also predicted that the incidence is expected to reach 29.5 million by 2040 [3-4]. Moreover, uncontrolled multiplication of normal cells leads to an accumulation of genetic instabilities and changes that transform into malignant cells with the potential of being metastatic. These genetic mutations are evoked by external factors such as smoking, tobacco, radiation, environmental pollution, heavy metals, and microbial infections, and internal factors such as multiple genetic reasons, hormonal disorders, and immune system [1-2, 5]. 
Common cancer treatments such as surgery, radiotherapy, and chemotherapy which are very costly and cause serious side effects on patients. Therefore, discovering efficacious anticancer agents with lower side effects is a serious challenge [6]. Recently, the use of plant extracts has appeared as a promising approach in controlling cancer cell proliferation. The World Health Organization stated that plant products are consumed by approximately $80 \%$ of Africans and Asians as traditional medicines. Meanwhile, some of these plant compounds show anticancer activity and are considered safer with less unexpected harmful effects. This has attracted many scientists worldwide in the prevention and treatment of cancer. Moreover, more than $60 \%$ of the current anticancer drugs are derived from natural products [7-8].

Pinus merkusii belongs to the Pinaceae family which is native to Southeast Asia and is widely distributed in Thailand, Burma, Laos, Vietnam, Cambodia, the Philippines, and Indonesia [9]. In Asia, pine trees are used as a folk remedy for dermatological and topical ailments, gastrointestinal disorders, inflammation, ulcers, itching, and snakebite treatment [10]. This pine genus is a source of antioxidants, especially phenolic compounds such as procyanidins, flavonoids, and phenolic acids. One of the pine products that are available in the market as a supplement is Pygnogenol ${ }^{\mathrm{TM}}$ which is a standardized Pinus Maritima bark extract [11]. Moreover, some of the recent studies have shown the anticancer activity of several species of the Pinaceae family [12-14]. However, there are no reports on the anticancer potential of Pinus merkusii needles. Therefore, this study aims to determine the anticancer activity of Pinus merkusii needle extract based on its cytotoxic effect on HeLa cervical cancer cells.

\section{Material and Methods}

\subsection{Ethical Clearance}

The treatment procedures were tested by the Medical and Health Research Ethics Committee, Faculty of Medicine, Universitas Gadjah Mada, Yogyakarta, Indonesia (KE/FK/0211/EC/2019).

\subsection{Chemicals and Reagents}

96\% of ethanol, Dimethyl Sulfoxide (DMSO) (Sigma-Aldrich, USA), Roswell Park Memorial Institute (RPMI) 1640 medium (Gibco ${ }^{\text {TM }}$, UK), Fetal Bovine Serum (Rocky Mountain Biologicals, Inc., USA), Penicillin Streptomycin (Gibco ${ }^{\mathrm{TM}}$, USA), Amphotericin B (Gibco, Israel), Dulbecco's Phosphate-Buffered Saline (DPBS) (Sigma-Aldrich, USA), TrypLETM Express Enzyme (1X) (Gibco ${ }^{\mathrm{TM}}$, USA), and 3-(4,5-dimethylthiazol-2yl)-2,5diphenyltetrazolium bromide (MTT) (Sigma-Aldrich, USA).

\subsection{Preparation of Pinus merkusii Needle Extract}

Leaves or needles of P. merkusii were taken from Kebumen Regency, Central Java, Indonesia. These needles were cleaned and dried at room temperature, cut into small pieces, and ground into powder. One kilogram of the powder was soaked in 3.5 liters of $96 \%$ ethanol for five days. The macerate was separated and concentrated using a rotary evaporator at a speed of $250 \mathrm{rpm}$ at $60^{\circ} \mathrm{C}$ [15]. 


\subsection{Cell Culture}

HeLa cells were provided by the Stem Cell Research and Development Center, Universitas Airlangga, Indonesia. These cells were grown in Roswell Park Memorial Institute (RPMI) 1640 medium that had been supplemented with 10\% Fetal Bovine Serum, 0.5\% Amphotericin B, and 2\% Penicillin Streptomycin. Furthermore, the cells were incubated at $37^{\circ} \mathrm{C}$ in a $5 \% \mathrm{CO}_{2}$ incubator.

\subsection{Cytotoxicity Assay and Data Analysis}

The cytotoxicity of $P$. merkusii needles extract (PMNE) was evaluated using 3-(4,5dimethylthiazol-2yl)-2,5-diphenyltetrazolium bromide (MTT) method [15]. The HeLa cells were seeded in 96 -well plates at a density of $1 \times 10^{4}$ cells/well overnight. Before the treatment, the medium was removed from all wells and the cells were treated with four concentrations of PMNE $(400,800$, and $1600 \mu \mathrm{g} / \mathrm{ml})$ for 24,48 , and 72 hours respectively. These cells were later administered with $25 \mu \mathrm{L}$ of MTT solution for $4 \mathrm{~h}$. After incubation, the cell condition was examined using an inverted microscope to observe the formazan crystals' formation. Subsequently, $50 \mu \mathrm{L}$ of DMSO was administered as the stopper and incubated in the dark at room temperature for 10 minutes. Furthermore, the absorbance was measured at $600 \mathrm{~nm}$ using GloMax ${ }^{\circledR}$ Explorer Multimode Microplate Reader (Promega, USA). The percentage of cytotoxicity was calculated, and the $\mathrm{IC}_{50}$ was determined by linear regression analysis using Microsoft Excel (Ms. Office 365).

\section{Results and Discussion}

The cytotoxic activity of the needle ethanolic extract of $P$. merkusii was evaluated by MTT assay. This technique was chosen because it is simple, reliable, and easily applicable to various types of cell lines. This assay involves a colorimetric reaction of MTT (3-(4,5dimethylthiazol-2-yl)-2,5-diphenyltetrazolium bromide) reagent with dehydrogenase enzyme present in living cells which reduced them to (E,Z)-5-(4,5-dimethylthiazol-2-yl)-1,3diphenylformazan in crystalline form and dark purple indicating the number of viable cells [4, 16-17].

Meanwhile, the MTT result showed that treated HeLa cells' cytotoxicity increased gradually with PMNE concentration and incubation time. The highest inhibition of HeLa cells was found at $48 \mathrm{~h}$ incubation of $1600 \mu \mathrm{g} / \mathrm{ml}$ PMNE with cytotoxicity of $94.21 \%$. The PMNE showed $\mathrm{IC}_{50}$ values of $1021.52,542.52$, and $1374.18 \mu \mathrm{g} / \mathrm{ml}$ at 24,48 , and $72 \mathrm{~h}$, respectively. This showed that PMNE inhibited the proliferation of HeLa cells in a time- and dose-dependent manner with the optimal treatment time at $48 \mathrm{~h}$ (Fig. 1). 


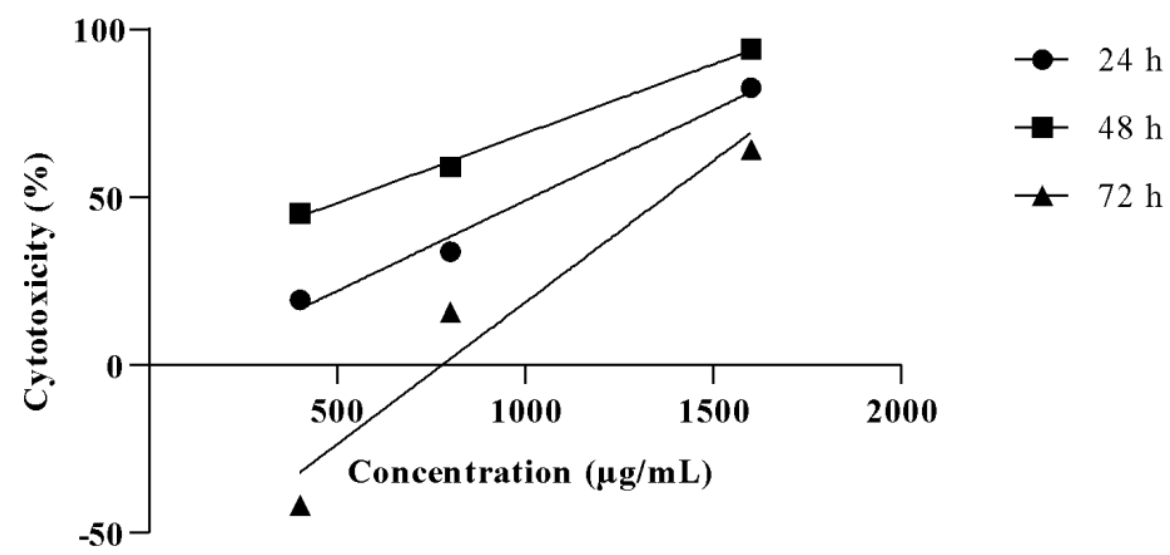

Fig. 1. Cytotoxic effect of PMNE on HeLa cells.

Despite the studies on the cytotoxicity of needle extracts of pine species needle extract $[10,18]$, there are no scientific reports on the therapeutic activity of Pinus merkusii needles in cervical cancer. The PMNE exhibits a growth-inhibiting effect, time- and dose-dependent with greater potency at 48 hours of therapy. This shows that PMNE triggers cellular processes that cause inhibition of cell proliferation and induced death.

Pinus merkusii contains procyanidins, which contribute to inhibiting cell proliferation inhibition and induces apoptosis in some cancer cells without any significant effect on normal cells [19-20]. Procyanidins isolated from Uncaria tomentosa L. include cytotoxic in AGS human gastric adenocarcinoma and SW620 human colon adenocarcinoma cells [21]. Moreover, $P$. massoniana bark proanthocyanidins were reported to initiate apoptosis and prevent cell migration of A2780 human ovarian cancer cells [22]. Meanwhile, it is difficult to explain the sensitivity of cells to anticancer agents by observing only one mechanism. Therefore, further study is recommended to explore the mechanism of PMNE as a candidate for a new anticancer agent.

\section{Conclusion}

Based on the results, the ethanol extract of Pinus merkusii needles has an antiproliferative effect on HeLa cells depending on the dose and treatment time. This study describes the potential of PMNE as a candidate for anticancer drugs, therefore, further study is recommended to determine the efficacy of this plant as a chemoprevention agent.

\section{References}

1. R.K. Upadhyay, Int J. Green Pharm., 12, S93-S107 (2018)

2. J. Iqbal, B.A. Abbasi, T. Mahmood, S. Kanwal, B. Ali, S.A. Shah, A.T. Khalil, Asian Pac J Trop Biomed, 7, 1129-1150 (2017)

3. F. Bray, J. Ferlay, I. Soerjomataram, R.L. Siegel, L.A. Torre, A. Jemal, CA Cancer J Clin., 68, 394-424 (2018)

4. Suciati, L. Arifianti, A Elsafira, L.Q. Ilmiah, J. Res. Pharm., 24, 218-224 (2018)

5. M. Greenwell and P.K.S.M. Rahman, Int. J. Pharm. Sci. Res., 6, 4103-4112 (2015)

6. A. Tariq, S. Mussarat, M. Adnan, J. Ethnopharm., 164, 96-119 (2015)

7. A.A. Al-Zahrani, Oncol. Rev., 12, 349 (2018) 
8. L. Nowacki, P. Vigneron, L. Rotellini, H. Cazzola, F. Merlier, E. Prost, R. Ralanairina, J.P., Gadonna, C. Rossi, M. Vayssade, Phytother. Res., 29, 1964-1973 (2015)

9. J. Hidayat, C.P. Hansen. Seed Leaflet, 60, 1-2 (2002)

10. A. Sajid, Q. Manzoor, M. Iqbal, A.K. Tyagi, R.A. Sarfraz, A. Sajid, EXCLI J.. 17, 233 245 (2018)

11. A. Koutsaviti, S. Toutoungy, R. Saliba, S. Loupassaki, O. Tzakou, V. Roussis, E. Ioannou, Foods. 10, 142 (2021)

12. J-R. Jo, J.S. Park, Y-K. Park, Y.Z. Chae, G-H. Lee, G-Y. Park, Int. J. Oncol., 40, 1238$1245(2012)$

13. S-M. Cho, E-O. Lee, S-H. Kim, H-J. Lee, BMC Complement. Altern. Med., 14, 275 (2014)

14. P. Kaushik, S.L. Khokra, A. Rana, D. Kaushik, Int. J. Pharmaceut. Clin. Res., 7, 105108 (2015).

15. A. Proboningrat, A. Fadholly, R.P.D. Iskandar, Vet. World, 12, 1616-1623 (2019)

16. K.E. Zulfafamy, Ardiansyah, S. Budijanto, Curr. Res. Nutr. Food Sci. J., 6, 23-24 (2018)

17. Y. Pan, Y.M. Zheng, W.S. Ho, Oncol. Lett., 15, 4657-4661 (2018)

18. N.T. Hoai, H.V. Duc, D.T. Thao, A. Orav, A. Raal, Phcog. Mag., 11, S290-S295 (2015)

19. A. Rauf, M. Imran, T. Abu-Izneid, Biomed. Pharmacother., 116, 1-6 (2019)

20. Y. Lee. Toxicol. Res., 33, 273-282 (2017)

21. M. Navarro-Hoyos, R. Lebron-Aguilar, J.E. Quintanilla-Lopez, Antioxidants, 6, 12 (2017)

22. J. Liu, J. Bai, G. Jiang. PLos ONE, 10, e0142157 (2015) 